\title{
The impact of Facebook on Zimbabwean University students: Culture Dilution or Pedagogical
}

\author{
Mr Jilson Zimuto \\ Marketing Department, Great Zimbabwe University, Zimbabwe \\ zimutojilson@gmail.com
}

\begin{abstract}
The study sought to establish consumer attitudes towards the effect of one Social Network Site (SNS), Facebook on culture dilution or pedagogical potential among university students. This has been necessitated by a plethora of unique social interactions in this era of technological affordances. Many SNSs are in use: Facebook, MySpace, Cyworld, Bebo, WhatsUp, Linkedln, ChatOn, Opera Mini, Twitter and other new forms keep on emerging. However, of interest Facebook was used in this study because it is impacting the ways in which university students use the Internet. Technology has mediated communication in countless ways. The values and norms of culture have to be cherished the young generation. In investigating this problem, two hundred (200) students were interviewed at their university campus in Zimbabwe. The sample comprised students from Great Zimbabwe University. The research findings proved that Facebook contributes to the dilution of the Zimbabwean culture. It was also interesting to note that other students see the pedagogical potentials of Facebook.
\end{abstract}

Key words: social network sites, Facebook, consumer attitudes, culture dilution, pedagogical potential

\section{Literature Review}

Social networking sites can be valuable sales and marketing tools, as well as fun diversions. Since their introduction, social network sites (SNSs) such as MySpace, Facebook, Linkedln and Bebo have attracted millions of users, many of whom have integrated these sites into daily practices (Danah Nicole 2007).

Researchers see SNSs as web-based services that allow individuals to construct a public or semi-public profile within a bounded system. Millions of people have joined social networking sites, adding profiles that reveal personal information. However, reputation of social networking sites has been diminished by a number of incidents publicized by the news media (Chiaramonte and Martinez, 2006, Hass, 2006, Mintz, 2005, Read, 2006). Is it possible to join a network of millions of people and be able to have your culture undiluted? This does not seem realistic. Since university students are obviously joining networks and revealing information, what impact do social networking sites have on culture and pedagogics?

Boyd and Ellison (2007) write: "What makes social network sites unique is not that they allow individuals to meet strangers, but rather that they enable users to articulate and make visible their social networks. This can result in connections between individuals that would not otherwise be made, but that is often not the goal, and these meetings are frequently between "latent ties" (Haythornthwaite, 2005). On many of the large social networking services, participants are not necessarily "networking" or looking to meet new people; instead, they are primarily communicating with people who are already a part of their extended social network (Boyd \& Ellison (2007). Thus the argument suggests that even Facebook is used in the same vein.

Ninety-six percent of the young people surveyed reported using some form of social networking technology, and the findings indicated that education-related topics are the most common, with $60 \%$ talking about education-related topics and $50 \%$ discussing their schoolwork (Boyd \& Ellison (2007). What is clear is that young people regard social networking sites as just another part of their social and often school-related activities.

\section{WHAT DO PEOPLE DO ON SOCIAL NETWORKING SERVICES?}

There is an ongoing debate concerning potentials of different forms of social interaction: groups, communities, collectives, connections and networks (Dron \& Anderson 2007; Downes 2007; Wenger et al. 2005; Anderson 2008; Ryberg \& Larsen 2008; Jones 2004; Jones et al. 2006; Siemens 2005). The debate has its origin in the concept of network, which challenges a number of other forms of social relations. As Dron \& Anderson (2007) state, research and practice of elearning has primarily focused on groups. They describe groups as "individuals who see themselves as part of that group". However, the approach also stresses that individual activities are always situated in a collective practice (Vygotsky, 1978; Brown, Collins \& Duguid, 1989). Individual activities always serve an objective, which relates to an overall collective activity (Bang \& Dalsgaard 2006). In fact words, activities are collective (Leont'ev 1978; Engeström 1987). The objective is not community-building or collaboration, but increased awareness. Supporting awareness within a learning environment is the focus of pedagogical potentials of social relations, researchers argue. This can also imply that at universities, students should make use of each other, since their work is relevant to each other.

Currently, there are no reliable data regarding how many people use SNSs, although marketing research indicates that SNSs are growing in popularity worldwide (comScore, 2007). The popularity of social networking sites has increased at astonishing levels. Usefulness of sites such as Facebook, WhatsUp and Linkedln has soared up in Zimbabwe.

\section{FACEBOOK}

Facebook, a social networking site that began with a focus on colleges and universities, attracted studies by Acquisti and Gross, 2006, Lampe, Ellison, and Steinfield, 2007, Stutzman, 2006. They show that Facebook members reveal a lot of 
information about themselves, and are not very aware of privacy options or who can actually view their profile (Acquisti and Gross, 2006).

The researchers acknowledge that in September 2005, Facebook expanded to include high school students, professionals inside corporate networks, and, eventually, everyone. Three of the most popular features of Facebook are the ability to add Friends, update one's status and run applications such as games and quizzes. A "Friend" is anyone on the Facebook network whom one allows to see various levels of personal information, such as job, birth date, photos, group membership, comments and list of other Friends. Friends can also see Friends of Friends, and may never have met, may have visibility into personal information and whereabouts (Acquisti and Gross, 2006).

Scholars are documenting the implications of SNSs use with respect to schools, universities, and libraries. For example, scholarship has examined how students feel about having professors on Facebook (Hewitt \& Forte, 2006) and how faculty participation affects student-professor relations (Mazer, Murphy, \& Simonds, 2007). Zimbabweans are people who uphold culture but universities have profusely increased and students use SNSs. It is against this background that the impact of SNSs on culture or education should be explored.

\section{METHODOLOGY}

The target population of the research was all fulltime university students in their first, second, third and fourth years of study. Due to the geographical spacing of universities and the large numbers of enrolment figures in universities it was not possible to send a questionnaire to all universities. A sample was collected from Great Zimbabwe University only. Stratified sampling was then applied taking level of study as a stratum. A series of linear regression were performed.

\section{DISCUSSION}

\section{The relationship between Facebook visits and educational purposes}

\section{Coefficients $^{\mathrm{a}}$}

\begin{tabular}{|c|c|c|c|c|c|c|}
\hline \multirow{2}{*}{\multicolumn{2}{|c|}{ Model }} & \multicolumn{2}{|c|}{ Unstandardized Coefficients } & \multirow{2}{*}{ 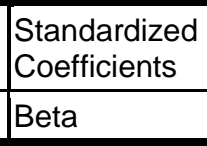 } & \multirow[b]{2}{*}{$\mathrm{t}$} & \multirow[b]{2}{*}{ Sig. } \\
\hline & & $B$ & Std. Error & & & \\
\hline 1 & $\begin{array}{l}\text { (Constant) } \\
\text { visits }\end{array}$ & $\begin{array}{l}1.357 \\
.214\end{array}$ & $\begin{array}{l}.286 \\
.092\end{array}$ & .164 & $\begin{array}{l}4.747 \\
2.334\end{array}$ & $\begin{array}{l}.000 \\
.021\end{array}$ \\
\hline
\end{tabular}

a. Dependent Variable: educational purpose

A one unit increase in Facebook visits increases educational purpose by 0.164 units. Facebook visit is significant in explaining educational purpose as given by the t-ratio of its coefficient 2.334 which is greater than 1.96. The hypothesis that Facebook visit is not for educational purposes is therefore rejected because some students use the Facebook for education.

\section{Coefficients $^{\mathrm{a}}$}

\section{Facebook visits and culture dilution}

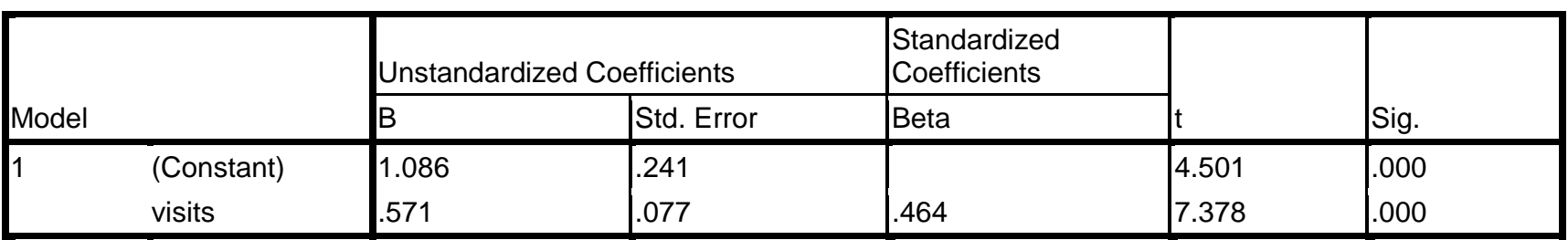

a. Dependent Variable: culture dilution

One unit increase in Facebook visits increases culture dilution by 0.464 and Facebook visit is very significant as depicted by the t-ratio of its coefficient 7.378 which is far greater than 1.96. The hypothesis that Facebook visit causes culture dilution is accepted.

\section{Coefficients $^{a}$}

The relationship between number of visits on Facebook and posting of bad behavior

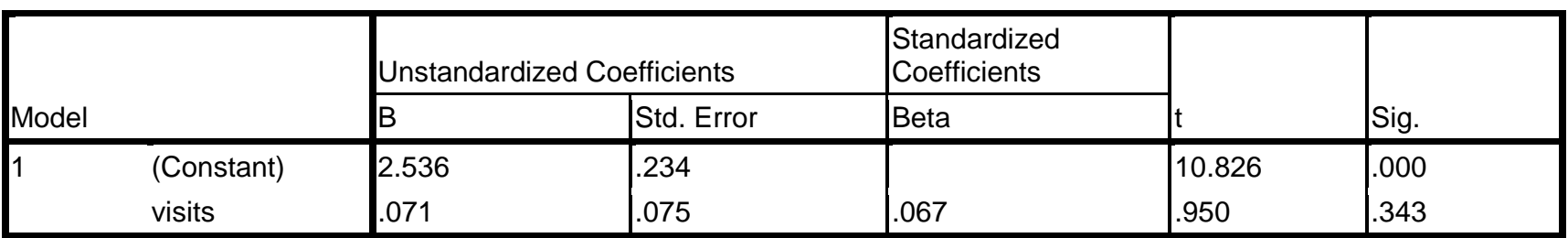

a. Dependent Variable: bad behavior

The table shows that a one unit increase in Facebook visits increases the bad behavior by 0.067 units. However, the influence of Facebook visits is not significant as measured by the t-ratio of its coefficient, 0.950 , which is not close to 1.96 . Therefore the hypothesis is rejected because not every student who visits Facebook has the intention of posting bad behavior. 


\section{Coefficients $^{a}$}

\begin{tabular}{|c|c|c|c|c|c|c|}
\hline \multirow{2}{*}{\multicolumn{2}{|c|}{ Model }} & \multicolumn{2}{|c|}{ Unstandardized Coefficients } & \multirow{2}{*}{$\begin{array}{l}\text { Standardized } \\
\text { Coefficients } \\
\text { Beta }\end{array}$} & \multirow[b]{2}{*}{$\mathrm{t}$} & \multirow[b]{2}{*}{ Sig. } \\
\hline & & $B$ & Std. Error & & & \\
\hline \multirow[t]{2}{*}{1} & (Constant) & .890 & .177 & & 5.023 & .000 \\
\hline & Overall perception & .749 & .066 & .629 & 11.388 & .000 \\
\hline
\end{tabular}

a. Dependent Variable: culture dilution

There is a one unit increase in overall perception of Facebook visits which increases culture dilution by 0.629 units. Overall perception is significant in explaining culture dilution as given by the t-ratio of its coefficient 11.388. Thus the overall perception that Facebook visits increases culture dilution hypothesis, is accepted.

The effect of level of study and number of visits on bad behavior on Facebook Coefficients $^{a}$

\begin{tabular}{|c|c|c|c|c|c|c|}
\hline & & Unstar & efficients & $\begin{array}{l}\text { Standardized } \\
\text { Coefficients }\end{array}$ & & \\
\hline & & $B$ & Std. Error & Beta & $\mathrm{t}$ & Sig. \\
\hline 1 & (Constant) & 5.786 & .539 & & 10.743 & .000 \\
\hline & level & -.867 & .132 & -.423 & -6.568 & .000 \\
\hline & visits & .071 & .068 & .067 & 1.046 & .297 \\
\hline
\end{tabular}

a. Dependent Variable: bad behavior

The level of study is significant in explaining bad behavior as measured by the t-ratio of its coefficient -6.568 . Whilst Facebook visits have some positive influence on bad behavior, it is not significant.

Coefficients $^{\mathrm{a}}$

Impact of Facebook visits, gender, program and level of study on culture dilution

\begin{tabular}{|c|c|c|c|c|c|c|}
\hline \multirow{2}{*}{\multicolumn{2}{|c|}{ Model }} & \multicolumn{2}{|c|}{ Unstandardized Coefficients } & \multirow{2}{*}{\begin{tabular}{|l} 
Standardized \\
Coefficients \\
Beta \\
\end{tabular}} & \multirow[b]{2}{*}{$\mathrm{t}$} & \multirow[b]{2}{*}{ Sig. } \\
\hline & & $B$ & Std. Error & & & \\
\hline \multirow[t]{5}{*}{1} & (Constant) & 2.634 & 1.290 & & 2.042 & .043 \\
\hline & visits & .580 & .084 & .471 & 6.907 & .000 \\
\hline & gender & .325 & .180 & .126 & 1.808 & .072 \\
\hline & program & -.265 & .142 & -.161 & -1.868 & .063 \\
\hline & level & -.427 & .210 & -.180 & -2.030 & .044 \\
\hline
\end{tabular}

a. Dependent Variable: culture dilution

A one unit increase in the level of study, decreases culture dilution by 0.180 units and the level of study is significant in explaining culture dilution. On the other hand, the program decreases culture dilution and it is not significant.

Overall perception on negative experience, abusive language, bad behavior, posting of something bad on

Coefficients $^{\mathrm{a}}$

Facebook and dilution of culture

\begin{tabular}{|c|c|c|c|c|c|c|}
\hline \multirow{2}{*}{\multicolumn{2}{|c|}{ Model }} & \multicolumn{2}{|c|}{ Unstandardized Coefficients } & \multirow{2}{*}{\begin{tabular}{|l|l}
$\begin{array}{l}\text { Standardized } \\
\text { Coefficients }\end{array}$ \\
Beta \\
\end{tabular}} & \multirow[b]{2}{*}{$\mathrm{t}$} & \multirow[b]{2}{*}{ Sig. } \\
\hline & & $B$ & Std. Error & & & \\
\hline \multirow[t]{6}{*}{1} & (Constant) & .249 & .176 & & 1.420 & .157 \\
\hline & Negative & .368 & .075 & .343 & 4.894 & .000 \\
\hline & abusive & -.306 & .112 & -.253 & -2.742 & .007 \\
\hline & Bad behavior & .180 & .063 & .185 & 2.860 & .005 \\
\hline & Postings & .398 & .090 & .439 & 4.422 & .000 \\
\hline & Culture dilution & .221 & .071 & .263 & 3.109 & .002 \\
\hline
\end{tabular}

\section{a. Dependent Variable: overall perception}

The overall perception about Facebook is that it is not generally used for educational purposes but otherwise for abusive language and posting of bad behavior that lead to culture dilution. There is need to promote university students to use it meaningfully.

\section{RECOMMENDATIONS}


It should be brought to the attention of the university students that Social Network Sites are also there for their educational use. Although some already employ the Facebook for sharing assignment, presentation and research information, its promotion may widen their pedagogical potential horizon. Secondly, students have to uphold Zimbabwean cultural values and norms when they communicate through Social Network Sites.

On the other hand, the work described in this paper contributes to an on- going discussion about the importance of social network sites. Vast, uncharted waters still remain to be explored. Scholars still have a limited understanding of what Facebook does to the Zimbabwean culture, especially in universities. Such a question requires large-scale quantitative and qualitative research. I hope that the work described here and included in this collection will help build a foundation for future investigations of issues surrounding other social network sites and the Zimbabwean culture.

\section{REFERENCES}

[1] Acquisti, A., \& Gross, R. (2006). Imagined communities: Awareness, information sharing, and privacy on the Facebook. In P. Golle \& G. Danezis (Eds.), Proceedings of $6^{\text {th }}$ Workshop on Privacy Enhancing Technologies (pp. 36-58). Cambridge, UK: Robinson College.

[2] Adamic, L. A., Büyükkökten, O., \& Adar, E. (2003). A social network caught in the Web. First Monday, 8 (6). Retrieved July 30, 2007 from http://www.firstmonday.org/issues/issue8_6/adamic/index.html

[3] Bahney, A. (2006, March 9). Don't talk to invisible strangers. New York Times. Retrieved July 21, 2007 from http://www.nytimes.com/2006/03/09/fashion/thursdaystyles/parents.html

[4] Barnes, S. (2006). A privacy paradox: Social networking in the United States. First Monday, 11 (9). Retrieved September 8, 2007 from http://www.firstmonday.org/issues/issue11 9/barnes/index.html

[5] BBC. (2005, July 19). News Corp in $\$ 580 \mathrm{~m}$ Internet buy. Retrieved July 21, 2007 from http://news.bbc.co.uk/2/hi/business/4695495.stm

[6] Benzie, R. (2007, May 3). Facebook banned for Ontario staffers. The Star. Retrieved July 21, 2007 from http://www.thestar.com/News/article/210014

[7] Boyd, d. (2004). Friendster and publicly articulated social networks. Proceedings of ACM Conference on Human Factors in Computing Systems (pp. 1279-1282). New York: ACM Press.

[8] Boyd, d. (2006a). Friends, Friendsters, and MySpace Top 8: Writing community into being on social network sites. First Monday, 11 (12). Retrieved July 21, 2007 from http://www.firstmonday.org/issues/issue11_12/boyd/

[9] Boyd, d. (2006b, March 21). Friendster lost steam. Is MySpace just a fad? Apophenia Blog. Retrieved July 21 2007 from http://www.danah.org/papers/FriendsterMySpaceEssay.html

[10] Boyd, d. (in press-a). Facebook's privacy trainwreck: Exposure, invasion, and social convergence. Convergence, 14 (1).

[11] Boyd, d. (in press-b). None of this is real. In J. Karaganis (Ed.), Structures of Participation. New York: Social Science Research Council.

[12] Boyd, d. (2008). Why youth (heart) social network sites: The role of networked publics in teenage social life. In D. Buckingham (Ed.), Youth, Identity, and Digital Media (pp. 119142). Cambridge, MA: MIT Press.

[13] Boyd, d., \& Heer, J. (2006). Profiles as conversation: Networked identity performance on Friendster. Proceedings of Thirty-Ninth Hawai'i International Conference on System Sciences. Los Alamitos, CA: IEEE Press.

[14] Byrne, D. (in press). The future of (the) 'race': Identity, discourse and the rise of computer- mediated public spheres. In A. Everett (Ed.), MacArthur Foundation Book Series on Digital Learning: Race and Ethnicity Volume (pp. 15-38). Cambridge, MA: MIT Press.

[15] Cassidy, J. (2006, May 15). Me media: How hanging out on the Internet became big business. The New Yorker, $82(13), 50$.

[16] Chafkin, M. (2007, June). How to kill a great idea!lnc. Magazine. Retrieved August 27, 2007 from http://www.inc.com/magazine/20070601/features-how-to-kill-a-great-idea.html

[17] Charnigo, L., \& Barnett-Ellis, P. (2007). Checking out Facebook.com: The impact of a digital trend on academic libraries. Information Technology and Libraries, 26 (1), 23.

[18] Choi, J. H. (2006). Living in Cyworld: Contextualising Cy-Ties in South Korea. In A. Bruns \& J. Jacobs (Eds.), Use of Blogs (Digital Formations) (pp. 173-186). New York: Peter Lang.

[19] Cohen, R. (2003, July 5). Livewire: Web sites try to make internet dating less creepy. Reuters. Retrieved July 5 , 2003 from http://asia.reuters.com/newsArticle.jhtml?type=internetNews\&story ID=3041934

[20] comScore. (2007). Social networking goes global. Reston, VA. Retrieved September 9, 2007 from http://www.comscore.com/press/release.asp?press=1555

[21] Consumer Affairs. (2006, February 5). Connecticut opens MySpace.com probe. Consumer Affairs. Retrieved July 21, 2007 from http://www.consumeraffairs.com/news04/2006/02/myspace.html

[22] Donath, J., \& boyd, d. (2004). Public displays of connection. BT Technology Journal, 22 (4), 71-82.

[23] Dwyer, C., Hiltz, S. R., \& Passerini, K. (2007). Trust and privacy concern within social networking sites: A comparison of Facebook and MySpace. Proceedings of AMCIS 2007,

[24] Keystone, CO. Retrieved September 21, 2007 from http://csis.pace.edu/ dwyer/research/DwyerAMCIS2007.pdf

[25] Ellison, N., Steinfield, C., \& Lampe, C. (2007). The benefits of Facebook "friends": Exploring the relationship between college students' use of online social networks and social capital. Journal of Computer-Mediated Communication, 12 (3), article 1. Retrieved July 30, 2007 from http://jcmc.indiana.edu/vol12/issue4/ellison.html

[26] Ewers, J. (2006, November 9). Cyworld: Bigger than YouTube? U.S. News \& World Report. Retrieved July 30, 2007 from LexisNexis.

[27] Festa, P. (2003, November 11). Investors snub Friendster in patent grab. CNet News.

[28] Retrieved August 26, 2007 from http://news.com.com/2100-1032_3-5106136.html 
[29] Finkelhor, D., Ybarra, M., Lenhart, A., boyd, d., \& Lordan, T. (2007, May 3). Just the facts about online youth victimization: Researchers present the facts and debunk myths. Internet Caucus Advisory Committee Event. Retrieved July 21, 2007 from

[30] http://www.netcaucus.org/events/2007/youth/20070503transcript.pdf

[31] Fono, D., \& Raynes-Goldie, K. (2006). Hyperfriendship and beyond: Friends and social norms on LiveJournal. In M. Consalvo \& C. Haythornthwaite (Eds.), Internet Research Annual Volume 4: Selected Papers from the AOIR Conference (pp. 91-103). New York: Peter Lang.

[32] Fragoso, S. (2006). WTF a crazy Brazilian invasion. In F. Sudweeks \& H. Hrachovec (Eds.), Proceedings of CATaC 2006 (pp. 255-274). Murdoch, Australia: Murdoch University.

[33] Frosch, D. (2007, May 15). Pentagon blocks 13 web sites from military computers. New York Times. Retrieved July 21, 2007 from http://www.nytimes.com/2007/05/15/washington/15block.html

[34] Gajjala, R. (2007). Shifting frames: Race, ethnicity, and intercultural communication in

[35] online social networking and virtual work. In M. B. Hinner (Ed.), The Role of Communication in Business Transactions and Relationships (pp. 257-276). New York: Peter Lang.

[36] Geidner, N. W., Flook, C. A., \& Bell, M. W. (2007, April). Masculinity and online social networks: Male selfidentification on Facebook.com. Paper presented at Eastern Communication Association 98th Annual Meeting, Providence, RI.

[37] George, A. (2006, September 18). Living online: The end of privacy? New Scientist, 2569. Retrieved August 29, $2007 \mathrm{from} \mathrm{http://www.newscientist.com/channel/tech/mg19125691.700-living-online-the-end-of-} \mathrm{privacy.html}$

[38] Goldberg, S. (2007, May 13). Analysis: Friendster is doing just fine. Digital Media Wire. Retrieved July 30,2007 from http://www.dmwmedia.com/news/2007/05/14/analysisfriendster-is-doing-just-fine

[39] Golder, S. A., Wilkinson, D., \& Huberman, B. A. (2007, June). Rhythms of social interaction: Messaging within a massive online network. In C. Steinfield, B. Pentland, M.

[40] Ackerman, \& N. Contractor (Eds.), Proceedings of Third International Conference on Communities and Technologies (pp. 41-66). London: Springer.

[41] Gross, R., \& Acquisti, A. (2005). Information revelation and privacy in online social networks. Proceedings of WPES'05 (pp. 71-80). Alexandria, VA: ACM.

[42] Haythornthwaite, C. (2005). Social networks and Internet connectivity effects. Information, Communication, \& Society, 8 (2), 125-147.

[43] Heer, J., \& boyd, d. (2005). Vizster: Visualizing online social networks. Proceedings of Symposium on Information Visualization (pp. 33-40). Minneapolis, MN: IEEE Press.

[44] Herring, S. C., Paolillo, J. C., Ramos Vielba, I., Kouper, I., Wright, E., Stoerger, S., Scheidt, L. A., \& Clark, B. (2007). Language networks on LiveJournal. Proceedings of the

[45] Fortieth Hawai'i International Conference on System Sciences. Los Alamitos, CA: IEEE Press.

[46] Hewitt, A., \& Forte, A. (2006, November). Crossing boundaries: Identity management and

[47] student/faculty relationships on the Facebook. Poster presented at CSCW, Banff, Alberta.

[48] Hjorth, L., \& Kim, H. (2005). Being there and being here: Gendered customising of mobile $3 G$ practices through a case study in Seoul. Convergence, 11 (2), 49-55.

[49] Hjorth, L., \& Yuji, M. (in press). Logging on locality: A cross-cultural case study of virtual communities Mixi (Japan) and Mini-hompy (Korea). In B. Smaill (Ed.), Youth and Media

[50] in the Asia Pacific. Cambridge, UK: Cambridge University Press.

[51] Hodge, M. J. (2006). The Fourth Amendment and privacy issues on the "new" Internet:

[52] Facebook.com and MySpace.com. Southern Illinois University Law Journal, 31, 95-122.

[53] Hogan, B. (in press). Analyzing social networks via the Internet. In N. Fielding, R. Lee, \&

[54] G. Blank (Eds.), Sage Handbook of Online Research Methods. Thousand Oaks, CA: Sage.

[55] H.R. 5319. (2006, May 9). Deleting Online Predators Act of 2006. H.R. 5319, 109th Congress. Retrieved July 21, 2007 from http://www.govtrack.us/congress/billtext.xpd?bill=h109-5319

[56] Hsu, W. H., Lancaster, J., Paradesi, M. S. R., \& Weninger, T. (2007). Structural link analysis from user profiles and friends networks: A feature construction approach. Proceedings of ICWSM-2007 (pp. 75-80). Boulder, CO.

[57] Jagatic, T., Johnson, N., Jakobsson, M., \& Menczer, F. (2007). Social phishing. Communications of the ACM, 5(10), 94-100.

[58] Kopytoff, V. (2004, November 29). Google's orkut puzzles experts. San Francisco Chronicle. Retrieved July 30, 2007 from http://www.sfgate.com/cgibin/article.cgi?f=/c/a/2004/11/29/BUGU9A0BH441.DTL

[59] Kornblum, J., \& Marklein, M. B. (2006, March 8). What you say online could haunt you. USA Today. Retrieved August 29, 2007 from http://www.usatoday.com/tech/news/internetprivacy/2006-03-08-facebook myspace_x.htm

[60] Kumar, R., Novak, J., \& Tomkins, A. (2006). Structure and evolution of online social networks. Proceedings of 12th International Conference on Knowledge Discovery in Data Mining (pp. 611-617). New York: ACM Press.

[61] Lampe, C., Ellison, N., \& Steinfield, C., (2006). A Face(book) in the crowd: Social searching vs. social browsing. Proceedings of CSCW-2006 (pp. 167-170). New York: ACM Press.

[62] Lampe, C., Ellison, N., \& Steinfeld, C. (2007). A familiar Face(book): Profile elements as signals in an online social network. Proceedings of Conference on Human Factors in Computing Systems (pp. 435-444). New York: ACM Press.

[63] Lenhart, A., \& Madden, M. (2007, April 18). Teens, privacy, \& online social networks.

[64] Pew Internet and American Life Project Report. Retrieved July 30, 2007 from http://www.pewinternet.org/pdfs/PIP_Teens_Privacy_SNS_Report_Final.pdf

[65] Liben-Nowell, D., Novak, J., Kumar, R., Raghavan, P., \& Tomkins, A. (2005) Geographic

[66] routing in social networks. Proceedings of National Academy of Sciences, 102 (33) 11,62311,628. 
[67] Liu, H., Maes, P., \& Davenport, G. (2006). Unraveling the taste fabric of social networks. International Journal on Semantic Web and Information Systems, 2 (1), 42-71.

[68] Madhavan, N. (2007, July 6). India gets more Net Cool. Hindustan Times. Retrieved July 30, 2007 from http://www.hindustantimes.com/StoryPage/StoryPage.aspx?id=f2565bb8663e-48c1-94ee-d99567577bdd

[69] Marwick, A. (2005, October). "I'm a lot more interesting than a Friendster profile:"

[70] Identity presentation, authenticity, and power in social networking services. Paper presented at Internet Research 6.0, Chicago, IL.

[71] Mazer, J. P., Murphy, R. E., \& Simonds, C. J. (2007). I'll see you on "Facebook:" The effects of computermediated teacher self-disclosure on student motivation, affective learning, and classroom climate. Communication Education, 56 (1), 1-17.

[72] McLeod, D. (2006, October 6). QQ Attracting eyeballs. Financial Mail (South Africa), p. 36. Retrieved July 30 , 2007 from LexisNexis.

[73] National School Boards Association. (2007, July). Creating and connecting: Research and guidelines on online social-and educational-networking. Alexandria, VA. Retrieved

[74] September 23, 2007 from http://www.nsba.org/site/docs/41400/41340.pdf Nyland, R., \& Near, C. (2007, February). Jesus is my friend: Religiosity as a mediating factor in Internet social networking use. Paper presented at AEJMC Midwinter Conference, Reno, NV.

[75] O'Shea, W. (2003, July 4-10). Six Degrees of sexual frustration: Connecting the dates with Friendster.com. Village Voice. Retrieved July 21, 2007 from http://www.villagevoice.com/news/0323,oshea,44576,1.html

[76] Paolillo, J. C., \& Wright, E. (2005). Social network analysis on the semantic web: Techniques and challenges for visualizing FOAF. In V. Geroimenko \& C. Chen (Eds.), Visualizing the Semantic Web (pp. 229-242). Berlin: Springer.

[77] Perkel, D. (in press). Copy and paste literacy? Literacy practices in the production of a MySpace profile. In K. Drotner, H. S. Jensen, \& K. Schroeder (Eds.), Informal Learning and Digital Media: Constructions, Contexts, Consequences. Newcastle, UK: Cambridge Scholars Press.

[78] Preibusch, S., Hoser, B., Gürses, S., \& Berendt, B. (2007, June). Ubiquitous social networks-opportunities and challenges for privacy-aware user modelling. Proceedings of

[79] Workshop on Data Mining for User Modeling. Corfu, Greece. Retrieved October 20, 2007 from http://vasarely.wiwi.hu-berlin.de/DM.UM07/Proceedings/05-Preibusch.pdf

[80] Recuero, R. (2005). O capital social em redes sociais na Internet. Revista FAMECOS, 28, 88-106. Retrieved September 13, 2007 from http://www.pucrs.br/famecos/pos/revfamecos/28/raquelrecuero.pdf S. 49. (2007, January 4). Protecting Children in the 21 st Century Act. S. 49, 110th

[81] Congress. Retrieved July 30, 2007 from http://thomas.loc.gov/cgi- bin/query/F?c110:1:./temp/ c110dJQpcy:e445:

[82] Shirky, C. (2003, May 13). People on page: YASNS... Corante's Many-to-Many. Retrieved July 21, 2007 from http://many.corante.com/archives/2003/05/12/people_on_page_yasns.php

[83] Skog, D. (2005). Social interaction in virtual communities: The significance of technology. International Journal of Web Based Communities, 1 (4), 464-474.

[84] Spertus, E., Sahami, M., \& Buyukkokten, O. (2005). Evaluating similarity measures: A large-scale study in the orkut social network. Proceedings of 11th International Conference on Knowledge Discovery in Data Mining (pp. 678-684). New York: ACM Press.

[85] Stutzman, F. (2006). An evaluation of identity-sharing behavior in social network communities. Journal of the International Digital Media and Arts Association, 3 (1), 10- 18.

[86] Sundén, J. (2003). Material Virtualities. New York: Peter Lang.

[87] Walther, J. B., Van Der Heide, B., Kim, S. Y., \& Westerman, D. (in press). The role of friends' appearance and behavior on evaluations of individuals on Facebook: Are we known by the company we keep? Human Communication Research.

[88] Wellman, B. (1988). Structural analysis: From method and metaphor to theory and substance. In B. Wellman \& S. D. Berkowitz (Eds.), Social Structures: A Network Approach (pp. 19-61). Cambridge, UK: Cambridge University Press.

[89] Wolak, J., Mitchell, K., \& Finkelhor, D. (2006). Online victimization of youth: Five years later. Report from Crimes Against Children Research Center, University of New Hampshire. Retrieved July 21, 2007 from http://www.unh.edu/ccrc/pdf/CV138.pdf

[90] Zinman, A., \& Donath, J. (2007, August). Is Britney Spears spam? Paper presented at the Fourth Conference on Email and Anti-Spam, Mountain View, CA. 